\title{
Analysis of the Application of Mutual Agreement Procedure (MAP) and Advance Pricing Agreement (APA) in Indonesia
}

\author{
Ernie*, Marcelino** $^{* *}$ \\ *Institut IImu Sosial dan Manajemen, Sekolah Tinggi Ilmu Administrasi Mandala Indonesia (STIAMI) \\ DOI: 10.29322/IJSRP.11.01.2021.p10964 \\ http://dx.doi.org/10.29322/IJSRP.11.01.2021.p10964
}

\begin{abstract}
The purpose of this research is to analyze the application of the Mutual Agreement Procedure (MAP) and / or Advance Pricing Agreement (APA) in Indonesia. This research will discuss about international tax disputes, the process of agreement or appeal (domestic settlement), the process of Mutual Agreement Procedure (MAP) and / or Advance Pricing Agreement (APA). Based on data obtained by the Directorate of International Taxation, it can be concluded that the minimum number of taxpayers who take advantage of the Mutual Agreement Procedure (MAP) and Advance Pricing Agreement (APA). This is because the implementation of these two facilities is new to taxpayers in
\end{abstract}

\section{INTRODUTION}

$\mathrm{T}^{\mathrm{he}}$ he author got the idea above when reading several articles on the internet that more taxpayers use the objection and appeal process (domestic remedies) than the Mutual Agreement Procedure (MAP) and Advance Pricing Agreement (APA) processes in resolving international tax disputes. Even though the Mutual Agreement Procedure (MAP) and Advance Pricing Agreement (APA) processes can be a solution to a deadlock in a case or complicated trial processes in the tax court and do not impose any fees on taxpayers. Therefore, the researcher wants to know why taxpayers prefer the process of objections and appeals (domestic remedies) than the Mutual Agreement Procedure (MAP) and Advance Pricing Agreement (APA) processes in resolving international tax disputes.

\section{METHOD}

Researchers used qualitative research methods as a method to evaluate cases.

\section{INTERNATIONAL TAX DISPUTES}

In general, international tax disputes that occur because of differences in tax authorities and taxpayers in these two issues. First, interpreting the Double Taxation

This publication is licensed under Creative Commons Attribution CC BY. http://dx.doi.org/10.29322/IJSRP.11.01.2021.p10964
Indonesia, so the tax authorities or the Directorate General of Taxes (DGT) must provide knowledge about the Mutual Agreement Procedure (MAP) and Advance Pricing Agreement (APA) to multinational taxpayers. In addition, the tax authority or DGT can at least begin by conducting more active outreach to taxpayers regarding the Mutual Agreement Procedure (MAP) and Advance Pricing Agreement (APA).

Index Terms - BEPS, Mutual Agreement Procedure (MAP), Advance Pricing Agreement (APA).

Avoidance Agreement (P3B) or P3B. Second, setting transfer prices (transfer prices) for transactions with affiliated parties (affiliated parties) across jurisdictions. So far, international tax dispute resolution has been more abundant than process or appeals (domestic settlement). In fact, the process of agreeing or appealing (household solutions) requires a large amount of money and time. As an illustration, taxpayers have to wait for the tax authority's decision on a request submitted for up to 12 months. While the tax request is rejected, the taxpayer must file an appeal to the tax court. The examination of an appeal case in the tax court is at most 15 months, but the decision can exceed that time period (Miarso, 2020).

Apart from dispute resolution and appeals, there are other more effective facilities for resolving international tax disputes, namely: Mutual Agreement Procedure (MAP) and / or Advance Pricing Agreement (APA). Mutual Agreement Procedure (MAP) is a regulation on the procedure for implementing the joint agreement with the double tax avoidance agreement, so that it is used to resolve ongoing disputes (such as transfer pricing disputes and / or tax treaty disputes). While. Advance Pricing Agreement (APA) is a regulation on the procedures for implementing transfer agreements, so it is used to determine a reasonable transfer price for multinational companies. 


\section{MUTUAL AGREEMENT PROCEDURE (MAP)}

Mutual Agreement Procedure (MAP) is a regulation on the procedure for implementing the joint approval procedure based on the double tax avoidance agreement (P3B), which is used to resolve administrative problems or disputes arising in the application of double tax avoidance agreements (P3B), including eliminating double taxation due to transfer pricing correction (Miarso, 2020).

Based on the Regulation of the Minister of Finance (PMK) No.49 / PMK.03 / 2019 article 3 paragraph 1, requests for implementation of the MAP are made before the deadline specified by the P3B or no later than 3 (three) years from the issuance of a tax assessment, date of proof of payment, deduction or collection of income tax $(\mathrm{PPh})$ and since tax treatment deemed inappropriate was carried out (Indonesia, 2019).

The Directorate General of Taxes (DGT) will conduct research on the required information and documents to determine whether the MAP application can be followed up or rejected. If the application is accepted, the DGT will follow up by conducting negotiations with the authorized official from the partner country. Negotiations are held a maximum of 24 months or two years from the time the application is received (Miarso, 2020).

\section{ADVANCE PRICING AGREEMENT (APA)}

Especially for taxpayers in transfer price disputes, they can resolve disputes by submitting an application for an Advance Pricing Agreement (APA). Advance Pricing Agreement (APA) is a regulation on the procedures for implementing transfer agreements, so it is used to determine a reasonable transfer price for multinational companies. Advance Pricing Agreement (APA) is an initial agreement between multinational companies and one or more tax authorities in other countries regarding the determination of fair transaction prices between parties with a special relationship. The Advance Pricing Agreement (APA) is not only unilateral, in which the formed relationship only involves taxpayers with one tax authority. This means that the Advance Pricing Agreement (APA) is also bilateral / multilateral, which in practice involves taxpayers with two or more tax authorities (Miarso, 2020).

The Directorate General of Taxation (DGT) will respond to the application for an Advance Price Agreement (APA) no later than 24 months after the application is submitted by the taxpayer and can be extended for another
24 months. Transfer agreements in the framework of Advanced Pricing Agreements (APA) for the transaction period of the next four years (Miarso, 2020).

Based on the Regulation of the Minister of Finance (PMK) No.22 / PMK.03 / 2020, determining a reasonable transfer price must be in accordance with the principles of fairness and business normality (Indonesia, 2020). Based on the Minister of Finance Regulation (PMK) No.22 / PMK.03 / 2020, there are several methods of determining fair transfer prices according to the principles of fairness and business normality.

a. The comparable uncontrolled price method, this method is often called CUP or Comparable Uncontrolled Price, aims to compare transaction prices between businesses that have a special relationship with similar businesses that have no special relationship (Mekari, 2020).

b. Resale price method. This method obtains the transfer price by using fair gross profit (mark up) as a deduction for the selling price. Reasonable gross profit (mark up) is obtained from the percentage of gross profit from similar businesses that have no special relationship (Mekari, 2020).

c. The cost-plus method. This method determines the transfer price with the gross profit from transactions between unrelated businesses in proportion to the costs incurred in similar related businesses. This method is more suitable for manufacturing companies that sell semi-finished goods (Mekari, 2020).

d. Other methods, such as:

1. profit sharing method (profit split method)

2. the transactional net margin method

3. the comparable uncontrolled transaction method

4. methods of valuing tangible assets and / or intangible assets (tangible assets and intangible asset valuations)

5. methods in business valuation

Based on the explanation of the above transfer pricing methods, it can be concluded that the determination of a fair transfer price must be in accordance with the principles of fairness and business normality. Depending on the comparative data obtained, the above methods can be used.

\section{PENERAPAN MUTUAL AGREEMENT PROCEDURE (MAP) DAN ADVANCE PRICING AGREEMENT (APA)}


The implementation of Mutual Agreement Procedure (MAP) and Advance Pricing Agreement (APA) is an attractive facility provided by the state. This policy can be a solution to the impasse or convoluted court process in the tax court. Moreover, the implementation of Mutual Agreement Procedure (MAP) and Advance Pricing Agreement (APA) in Indonesia does not impose any fees on taxpayers. This is different from a number of other countries, which take into account the costs of negotiating Mutual Agreement Procedure (MAP) and Advance Pricing Agreement (APA). However, Indonesian taxpayers do not use this facility much. This is evidenced by the accumulative data on requests and dispute resolution using Mutual Agreement Procedure (MAP) and Advance Pricing Agreement (APA) facilities. The following is the accumulative statistical data on requests and dispute resolution using the Mutual Agreement Procedure (MAP) and Advance Pricing Agreement (APA) facilities obtained from the Directorate of International Taxation (Miarso, 2020).

\begin{tabular}{c|l|r|r|r|} 
Year & Description & \multicolumn{1}{l|}{ MAP } & \multicolumn{1}{l|}{ APA } & \multicolumn{1}{l|}{ Total } \\
\hline \multirow{4}{*}{ Pre-2016 } & Requests Received & 69 & 14 & 83 \\
\cline { 2 - 5 } & Requests Closed & 1 & - & 1 \\
\cline { 2 - 5 } & Ending Balance & 68 & 14 & 82 \\
\hline \multirow{4}{*}{2016} & Requests Received & 19 & 25 & 44 \\
\cline { 2 - 5 } & Requests Closed & 32 & 3 & 35 \\
\cline { 2 - 5 } & Ending Balance & 55 & 36 & 91 \\
\hline \multirow{5}{*}{2017} & Requests Received & 16 & 2 & 18 \\
\cline { 2 - 5 } & Requests Closed & 20 & 3 & 23 \\
\cline { 2 - 5 } & Ending Balance & 51 & 35 & 86 \\
\hline \multirow{3}{*}{2018} & Requests Received & 26 & 13 & 39 \\
\cline { 2 - 5 } & Requests Closed & 17 & 15 & 32 \\
\cline { 2 - 5 } & Ending Balance & 60 & 33 & 93 \\
\hline
\end{tabular}

(Source: Directorate of International Taxation)

Based on the table above, it can be concluded that the minimum number of taxpayers who utilize the Mutual Agreement Procedure (MAP) and Advance Pricing Agreement (APA) facilities in Indonesia. Even though the two facilities have been adopted by Indonesia since 2010 . This is because in practice the Mutual Agreement Procedure (MAP) and Advance Pricing Agreement (APA) are new things for taxpayers in Indonesia, so that taxpayers' doubts arise about the Mutual Agreement Procedure (MAP) facility. ) and an Advance Pricing Agreement (APA). To overcome this, the tax authority or the Directorate General of Taxes (DGT) must provide knowledge on the Mutual Agreement
Procedure (MAP) and Advance Pricing Agreement (APA) to multinational taxpayers. In addition, the Mutual Agreement Procedure (MAP) and Advance Pricing Agreement (APA) processes need cooperation and good faith from taxpayers and tax authorities to ensure the success of the process.

\section{CONCLUSIONS}

Based on the above statement the authors draw the following conclusions:

1. International tax disputes occur because of differences in tax authorities and taxpayers in the matter of interpretation of the Double Taxation Avoidance Agreement (P3B) or Tax Treaty and / or transfer pricing for transactions with affiliated parties across jurisdictions.

2. Most of the settlement of international tax disputes by taxpayers through the process of objections or appeals (domestic remedies). In fact, this process requires a lot of money and time.

3. Mutual Agreement Procedure (MAP) is an arrangement on the procedure for implementing a joint agreement procedure based on a double tax avoidance agreement (P3B), which is used to resolve administrative problems or disputes arising in the application of a double tax avoidance agreement. (P3B), including tax write-off. doubled due to transfer price corrections.

4. Advance Pricing Agreement (APA) is an arrangement on the procedure for implementing a transfer price agreement, so that it is used to determine a reasonable transfer price for multinational companies.

5. Implementation of Mutual Agreement Procedure (MAP) and Advance Pricing Agreement (APA) is a facility that can be a solution for cases that have reached a dead end or complicated trial processes in tax court and do not charge taxpayers any fees.

6. The lack of taxpayers who use the Mutual Agreement Procedure (MAP) and Advance Pricing Agreement (APA) facilities, because in practice these two facilities are still new to taxpayers in Indonesia, as well as the tax authorities or the Directorate General of Taxes (DGT) are obliged to provide knowledge of Mutual Agreement Procedure (MAP) and Advance Pricing Agreement (APA) for multinational taxpayers.

7. In addition, the Mutual Agreement Procedure (MAP) and Advance Pricing Agreement (APA) processes require cooperation and good faith from 
taxpayers and tax authorities to ensure the success of the process.

\section{SUGGESTION}

Based on the above conclusions, the authors provide the following suggestions:

1. For taxpayers, to ensure that the MAP and APA applications are well responded to by the DGT, it is not enough just to fulfill administrative requirements. Transparency and disclosure of financial information are the main keys for taxpayers to be able to maximize the MAP and APA options.

2. For tax authorities, they must have the enthusiasm to serve taxpayers who apply for MAP and APA, if they want to reduce the burden of objections and appeals that accumulate every year. The seriousness of the DGT at least can be started by conducting more active outreach to taxpayers regarding the dispute resolution facility which has long been initiated by the OECD and G20.

\section{REFERENCES}

Indonesia, R. (2019). TATA CARA PELAKSANAAN PROSEDUR PERSETUJUAN BERSAMA.

Indonesia, R. (2020). TATA CARA PELAKSANAAN KESEPAKATAN HARGA TRANSFER (ADVANCE PRICING AGREEMENT ). Peraturan Menteri Keuangan Republik Indonesia.

Mekari. (2020). 5 Metode Penentuan Transfer Pricing yang Wajar. Klikpajak. https://klikpajak.id/blog/beritaregulasi/metode-tansfer-pricing-pajak-wajar/

Miarso, K. (2020). Solusi Alternatif Sengketa Pajak Internasional. MUC Consulting. https://mucglobal.com/id/news/593/solusi-alternatifsengketa-pajak-internasional 